\title{
ADOLESCENT IDIOPATHIC SCOLIOSIS: EVALUATION ON THE EFFECT OF SCREW DENSITY IN THE CORRECTION
}

\author{
ESCOLIOSE IDIOPÁTICA DO ADOLESCENTE: AVALIAÇÃO DO EFEITO DA DENSIDADE DOS \\ PARAFUSOS NA CORREÇÃO
}

ESCOLIOSIS IDIOPÁTICA DEL ADOLESCENTE: EVALUACIÓN DEL EFECTO
DE LA DENSIDAD DE LOS TORNILLOS EN LA CORRECCIÓN

\author{
Enguer Beraldo Garcia ${ }^{1}$, Liliane Faria Garcia ${ }^{1}$, Enguer Beraldo Garcia Jr¹ ${ }^{1}$. Roberto Garcia Gonçalves ${ }^{1}$, Saulo Terror Giesbrecht ${ }^{1}$, \\ Fernando Henrique Rocha de Oliveira', Vinícius Augusto Batista', Wendel Parreira Costa ${ }^{1}$ \\ 1. Hospital Santa Casa de Belo Horizonte, MG, Brazil
}

\begin{abstract}
Objective: The objective was to investigate implant density or the number of screws correlated with the correction of the main curve in patients undergoing surgery for adolescent idiopathic scoliosis (AIS). Methods: We evaluated 112 medical records: 33 patients with screw density of up to $50 \%$, and 79 patients with a density of $100 \%$; all patients underwent surgical correction by posterior approach with transpedicular fixation. Results: In the group of patients with screw density of up to $50 \%$ the residual Cobb median was $10^{\circ}$; in the group with $100 \%$ density, the median was $7^{\circ}$. Conclusion: Biostatistical analysis showed that the group with up to $50 \%$ of screw density presented correction rate of $82.1 \%$ and the group with $100 \%$ density had correction of about $86.8 \%$. It is therefore concluded that the difference is statistically significant in favor of the fixation with $100 \%$ density $(p=0.010)$.
\end{abstract}

Keywords: Scoliosis; Adolescent; Pedicle screws.

\begin{abstract}
RESUMO
Objetivo: O objetivo foi investigar a densidade do implante ou o número de parafusos correlacionados com a correção da curva principal em pacientes operados em decorrência de escoliose idiopática do adolescente (EIA). Métodos: Avaliaram-se 112 prontuários: 33 pacientes com densidade de parafusos de até 50\% e 79 pacientes com densidade de parafusos de 100\%; todos os pacientes foram submetidos à correção cirúrgica por via posterior, com fixação transpedicular. Resultados: No grupo de pacientes com fixação de até 50\% de densidade de parafusos, o Cobb residual apresentou mediana de 10 ; no grupo com 100\% de densidade, a mediana foi $7^{\circ}$. Conclusão: O estudo bioestatístico mostrou que o grupo com até $50 \%$ de densidade de parafusos, apresentou taxa de correção de $82,1 \%$ e o grupo com 100\% de densidade teve correção de cerca de 86,8\%. Conclui-se, portanto, que a diferença é estatisticamente significativa a favor da fixação com densidade de 100\% $(p=0,010)$.
\end{abstract}

Descritores: Escoliose; Adolescente; Parafusos pediculares.

\section{RESUMEN}

Objetivo: El objetivo fue investigar la densidad del implante o el número de tornillos correlacionados con la corrección de la curva principal en pacientes sometidos a cirugía debido a escoliosis idiopática del adolescente (EIA). Métodos: Se evaluaron 112 registros: 33 pacientes con tornillos de densidad de hasta 50\%, 79 pacientes con densidad de $100 \%$; todos los pacientes fueron sometidos a corrección quirúrgica por vía posterior con fijación transpedicular. Resultados: En el grupo de pacientes con tornillos de 50\% de densidad, la mediana residual de Cobb fue $10^{\circ}$; en el grupo con densidad de $100 \%$, la mediana fue $7^{\circ}$. Conclusión: El estudio de bioestadística mostró que el grupo con tornillos de hasta $50 \%$ de densidad, tuvo tasa de corrección de 82,1\% y el grupo con densidad de 100\% tuvo corrección de aproximadamente 86,8\%. Por tanto, se concluye que la diferencia es estadísticamente significativa a favor de la fijación con una densidad de 100\% $(p=0,010)$.

Descriptores: Escoliosis; Adolescente; Tornillos pediculares.

\section{INTRODUCTION}

Scoliosis is a complex three-dimensional deformity of the vertebrae and ribcage, with deviations in the sagittal, coronal, and horizontal planes. It is a common disease, affecting 2 to $3 \%$ of the population, most commonly in its idiopathic form (80 to $90 \%$ of cases) and is most often diagnosed in adolescence. Approximately $10 \%$ of patients need treatment and $0.1 \%$ require surgical treatment. ${ }^{1}$

Clements et al. ${ }^{2}$ described the term implant density (the ratio between the number of implants used in the assembly divided by the number of pedicles available $X 100$ ).

The surgical treatment method has evolved greatly in the past few decades. The Harrington fixation system, which uses a rod to distract the concavity and a compressor in the cavity, was the first instrumentation method for the surgical treatment of AIS. The Luque technique uses an instrumentation comprised of L-rods and sublaminal steel thread; this was later combined with Harrington rods, providing greater stability, but with greater neurological risk. The Cotrel-Dobouset fixation method uses two multiple hook rods with posterior and lateral openings, enabling a higher number of implants and better distribution of load on the vertebrae, achieving better outcomes. More recently, the fixation system has been modernized with pedicle screws, resulting in a higher rate of correction and a lower rate of complications. ${ }^{3}$ 
Garcia et al. ${ }^{4}$ obtained statistically significant correction in the coronal plane in 36 patients with AIS.

The aim of this study was to investigate implant density or the number of screws in relation to the correction of the primary curve, in patients who underwent surgery for AIS.

\section{MATERIAL AND METHOD}

This is a retrospective study of 284 patients representing the 6 Lenke types, surgically treated for AIS with bilateral posterior segmental instrumentation performed by a single spine surgeon. Forty-five patients with incomplete or missing medical records, 37 patients recently operated but not yet evaluated, and $90 \mathrm{ca}-$ ses with screw density between $50.1 \%$ and $99.9 \%$, were excluded. The study was approved by the Ethics Committee (CAA: 312666214.6.0000.5138)

A total of 112 twelve patient records were included: 33 patients with screw density up to $50 \%$, and 79 patients with $100 \%$ screw density.

All patients underwent posterior approach corrective surgery with transpedicular fixation connected to two longitudinal rods, molded to preserve sagittal balance, and locked into the transverse devices using clamps and fixation. A combination of anterior and posterior approaches was used in rigid deformities greater than $70^{\circ}$, curves with the potential to worsen, young patients, and cases with marked vertebral rotation.

Pearson's chi-square test, Fisher's exact test, the Mann-Whitney non-parametric test, and the PASW statistical program, version 18 , were used. In all the statistical tests performed, a significance level of $5 \%$ was used, with $p$ values less than 0.05 considered to be statistically significant.

\section{RESULTS}

The distribution of fixed pedicle screw density is shown in Figure 1.

As shown in Figure 1,79 patients had a fixed pedicle screw density of $100 \%$, while the other 33 patients had fixed pedicle screw density of less than $50 \%$.

According to the results in the histogram in Figure 1, the study patients were separated into two groups (with up to 50\% fixed pedicle screw density and $100 \%$ fixed pedicle screw density). In terms of sample size, 33 patients $(29.5 \%)$ underwent correction for scoliosis with fixed pedicle screw density of up to $50 \%$ and 79 patients $(70.5 \%)$ underwent correction for scoliosis with fixed pedicle screw density of $100 \%$. Figure 2 illustrates this distribution.

Analyzing the association between the sex of the patient and

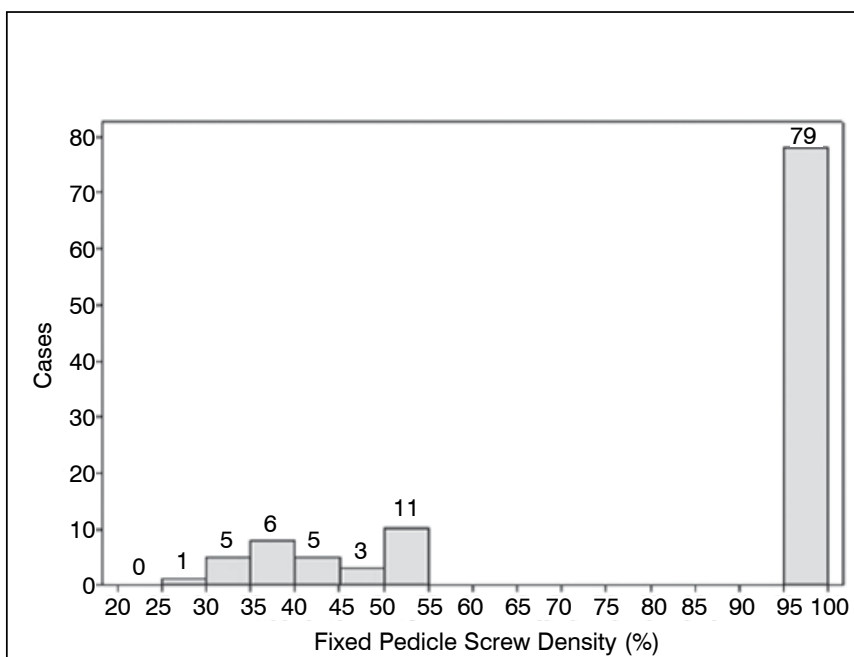

Figure 1. Distribution of Fixed Pedicle Screw Density for the total sample. the patient group (patients who underwent correction for scoliosis with fixed pedicle screw density of up to $50 \%$ and patients who underwent correction for scoliosis with fixed pedicle screw density of $100 \%)$, we observed that these variables are mutually independent, or unrelated, since the p-value was greater than 0.05 . This is demonstrated by the fact that $94.9 \%$ of the $100 \%$ fixed pedicle screw density group were women and $90.9 \%$ of the up to $50 \%$ fixed pedicle screw density group were also women (Table 1).

We observed that the variable of race was mutually independent or unrelated between the two groups, with a p-value higher than 0.05 . This is supported by the fact that $78.2 \%$ of the $100 \%$ fixed pedicle screw density group were White and $69.7 \%$ of the up to $50 \%$ fixed pedicle screw density group were also White. (Table 1 )

The mean age of the group with $100 \%$ fixed pedicle screw density was 15 years of age, while the mean age of the up to $50 \%$ fixed pedicle screw density group was 16 years of age. No statistically significant difference between the ages of the two patient groups was identified by using the Mann-Whitney statistical test. (Table 2)

Regarding the preoperative variable Cobb angle, the hypothesis that the means of both fixed pedicle groups are equal (given that the p-value was greater than 0.05) was confirmed (Table 2) by the fact that there were no statistically significant differences between the mean values. The mean for the preoperative Cobb variable was $53^{\circ}$ in the $100 \%$ fixed pedicle screw density group and $56^{\circ}$ in the up to $50 \%$ fixed screw density group.

In Table 2, the Mann-Whitney test results show that the 2 groups (100\% fixation screw density and up to $50 \%$ fixation screw density) had a statistically significant difference in the postoperative Cobb variable. The group of patients with up to $50 \%$ fixed pedicle screw

Table 1. Frequency distribution of the 33 patients with up to $50 \%$ fixed pedicle screw density and the 79 patients with 100\% fixed pedicle screw density by demographics characteristics.

\begin{tabular}{c|c|c|c|c|c}
\hline \multirow{2}{*}{ Variables } & \multicolumn{2}{|c|}{$\begin{array}{c}100 \% \text { pedicle } \\
\text { screw density }\end{array}$} & \multicolumn{2}{c|}{$\begin{array}{r}\text { Up to 50\% pedicle } \\
\text { screw density }\end{array}$} & \multirow{2}{*}{ p-value } \\
\cline { 2 - 5 } & $\mathrm{N}$ & $\%$ & $\mathrm{~N}$ & $\%$ & \\
\hline Sex & & & & & \\
\hline Female & 75 & $94.9 \%$ & 30 & $90.9 \%$ & \multirow{2}{*}{0.418} \\
\hline Male & 4 & $5.1 \%$ & 3 & $9.1 \%$ & \\
\hline Race & & & & & \\
\hline White & 61 & $78.2 \%$ & 23 & $69.7 \%$ & \multirow{2}{*}{0.551} \\
\hline Mixed Race & 12 & $15.4 \%$ & 6 & $18.2 \%$ & \\
\hline Black & 5 & $6.4 \%$ & 4 & $12.1 \%$ & \\
\hline Total & 79 & 100 & 33 & 100 & \\
\hline
\end{tabular}

Note: $p$-value: descriptive level of the chi-square test

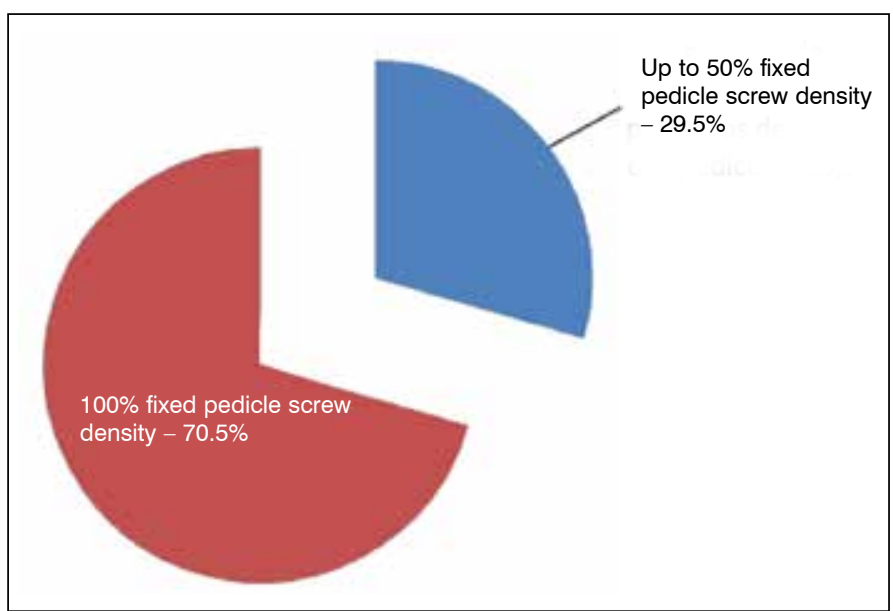

Figure 2. Distribution of the sample by fixed pedicle screw density patient groups. 
density had a greater mean value for this variable than the $100 \%$ fixed pedicle screw density group, at $10^{\circ}$ and $7^{\circ}$, respectively.

We also observed that the group with $50 \%$ fixed pedicle screw density had a mean preoperative Cobb angle of $56^{\circ}$, while the mean postoperative Cobb angle was $10^{\circ}$. A comparison between these two mean values shows a reduction of approximately $82.1 \%$ in postoperative Cobb in relation to the preoperative Cobb. In the $100 \%$ fixed pedicle screw density group, the mean preoperative Cobb was $53^{\circ}$, while the mean postoperative Cobb was $7^{\circ}$. A comparison of these two mean values shows a reduction of $86.8 \%$ from the preoperative Cobb to the postoperative Cobb. As confirmed by the statistical test, the difference between the percentages of the two groups analyzed was considered to be significant.

In terms of the number of screws, the $100 \%$ fixed pedicle screw density group had a statistically greater number (20 screws) than the group with up to $50 \%$ fixed pedicle screw density ( 9 screws). (Table 2 )

The data revealed no statistical difference between the two groups when the Lenke variable of the patients was analyzed. (Table 2 and Figure 3)

To summarize, in terms of the variables analyzed (sex, age, race, Lenke, and preoperative), no statistical difference was identified between the groups analyzed in this study (patients who underwent correction for scoliosis with up to $50 \%$ fixed pedicle screw density and patients who underwent correction for scoliosis with $100 \%$ fixed pedicle screw density), meaning that the groups are homogenous for these variables.

In terms of the postoperative variable, the Mann-Whitney test showed that the two groups had a statistically significant difference. (Figures 4 to 10)

Table 2. Frequency distribution of the 33 patients with up to $50 \%$ fixed pedicle screw density and the 79 patients with $100 \%$ fixed pedicle screw density by age, preoperative and postoperative Cobb angles, number of screws, and Lenke.

\begin{tabular}{|c|c|c|c|c|c|c|c|c|}
\hline \multirow{2}{*}{ Variable } & \multirow{2}{*}{ Group } & \multicolumn{5}{|c|}{ Descriptive Measurements } & \multirow{2}{*}{ P-value } & \multirow[b]{2}{*}{ Conclusion } \\
\hline & & Average & SD & P25 & Mean & P75 & & \\
\hline \multirow{2}{*}{ Age } & $100 \%$ Fixed & 15.72 & 3.60 & 14.00 & 15.00 & 16.25 & \multirow{2}{*}{0.346} & \multirow{2}{*}{$\begin{array}{c}100 \% \\
\text { Fix }=50 \% \\
\text { Fix. }\end{array}$} \\
\hline & $\begin{array}{c}\text { Up to } 50 \% \\
\text { Fixed }\end{array}$ & 16.00 & 3.01 & 14.00 & 16.00 & 17.50 & & \\
\hline \multirow{2}{*}{ PreCobb } & $100 \%$ Fixed & 58.52 & 15.53 & 46.00 & 53.00 & 70.00 & \multirow{2}{*}{0.924} & \multirow{2}{*}{$\begin{array}{c}100 \% \\
\text { Fix }=50 \% \\
\text { Fix. }\end{array}$} \\
\hline & $\begin{array}{l}\text { Up to } 50 \% \\
\text { Fixed }\end{array}$ & 58.24 & 15.98 & 46.00 & 56.00 & 64.00 & & \\
\hline \multirow{2}{*}{$\begin{array}{c}\text { PostCo- } \\
\text { bb }\end{array}$} & $100 \%$ Fixed & 8.37 & 5.86 & 4.00 & 7.00 & 12.00 & \multirow{2}{*}{$0.010^{*}$} & \multirow{2}{*}{$\begin{array}{c}100 \% \text { Fix }< \\
50 \% \text { Fix. }\end{array}$} \\
\hline & $\begin{array}{c}\text { Up to } 50 \% \\
\text { Fixed }\end{array}$ & 13.67 & 13.65 & 6.00 & 10.00 & 18.00 & & \\
\hline \multirow{2}{*}{$\begin{array}{l}\text { Num- } \\
\text { ber of } \\
\text { Screws }\end{array}$} & $100 \%$ Fixed & 18.99 & 4.27 & 16.00 & 20.00 & 22.00 & \multirow{2}{*}{$p<0.001^{*}$} & \multirow{2}{*}{$\begin{array}{c}100 \% \text { Fix }> \\
50 \% \text { Fix. }\end{array}$} \\
\hline & $\begin{array}{l}\text { Up to } 50 \% \\
\text { Fixed }\end{array}$ & 9.15 & 2.09 & 8.00 & 9.00 & 10.00 & & \\
\hline \multirow{2}{*}{ Lenke } & $100 \%$ Fixed & 3.35 & 1.92 & 1.00 & 3.00 & 5.00 & \multirow{2}{*}{0.863} & \multirow{2}{*}{$\begin{array}{c}100 \% \\
\text { Fix }=50 \% \\
\text { Fix. }\end{array}$} \\
\hline & $\begin{array}{c}\text { Up to } 50 \% \\
\text { Fixed }\end{array}$ & 3.36 & 1.90 & 2.00 & 3.00 & 6.00 & & \\
\hline
\end{tabular}

Note: The probabilities of significance ( $\mathrm{p}$-values) are in reference to the Mann-Whitney test.

\section{DISCUSSION}

Clements et al. ${ }^{2}$ described the term implant density (the ratio between the number of implants used in the assembly divided by the number of pedicles available $X 100$ ). They conducted a prospective multicenter study of 292 patients with curves of all six Lenke types. They found a significant positive correlation between a higher implant density and the percentage of curve correction. The higher the implant density, the greater the postoperative reduction of the kyphosis. ${ }^{2}$

Chen et al. ${ }^{5}$ published a retrospective study of 39 patients with AIS (Lenke 5). Without taking the flexibility of the curve into account, implant density had a positive correlation with the correction.

Larson et al. ${ }^{6}$ conducted a retrospective study of 952 patients who underwent surgery for AIS (Lenke 1, 2, and 5). Among the Lenke 1 and 2 cases, there was a higher percentage of correction of the primary curve in the patients with greater screw density. There was no association between screw density and outcome for the Lenke 5 curves.

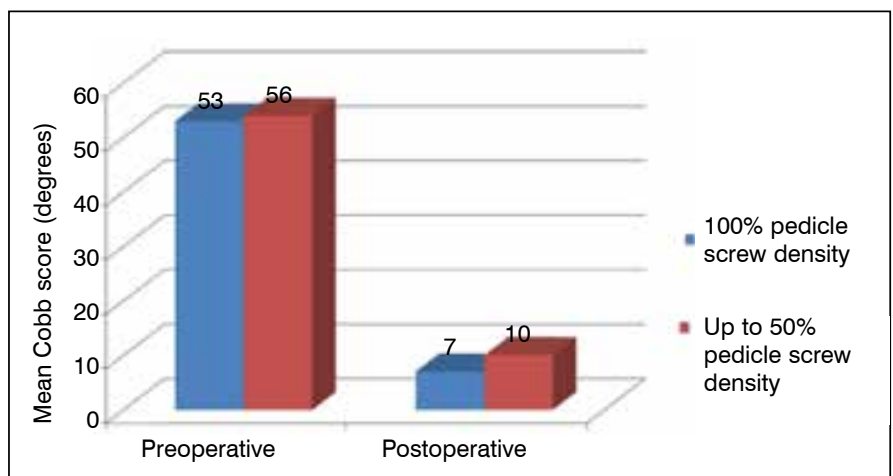

Figure 3. Comparison of 33 patients with up to $50 \%$ fixed pedicle screw density and 79 patients with $100 \%$ fixed pedicel screw density by preoperative and postoperative Cobb angles.

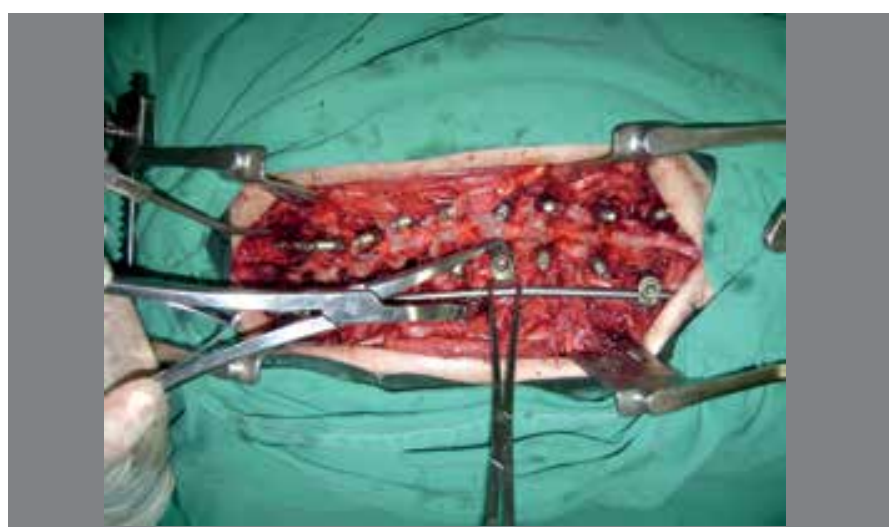

Figure 4. Instrumentation of $100 \%$ of the pedicles.

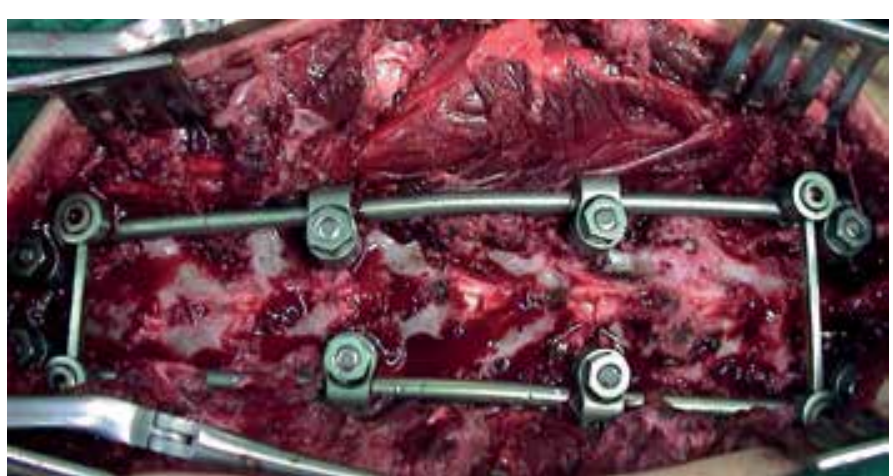

Figure 5. Instrumentation of up to $50 \%$ of the pedicles 


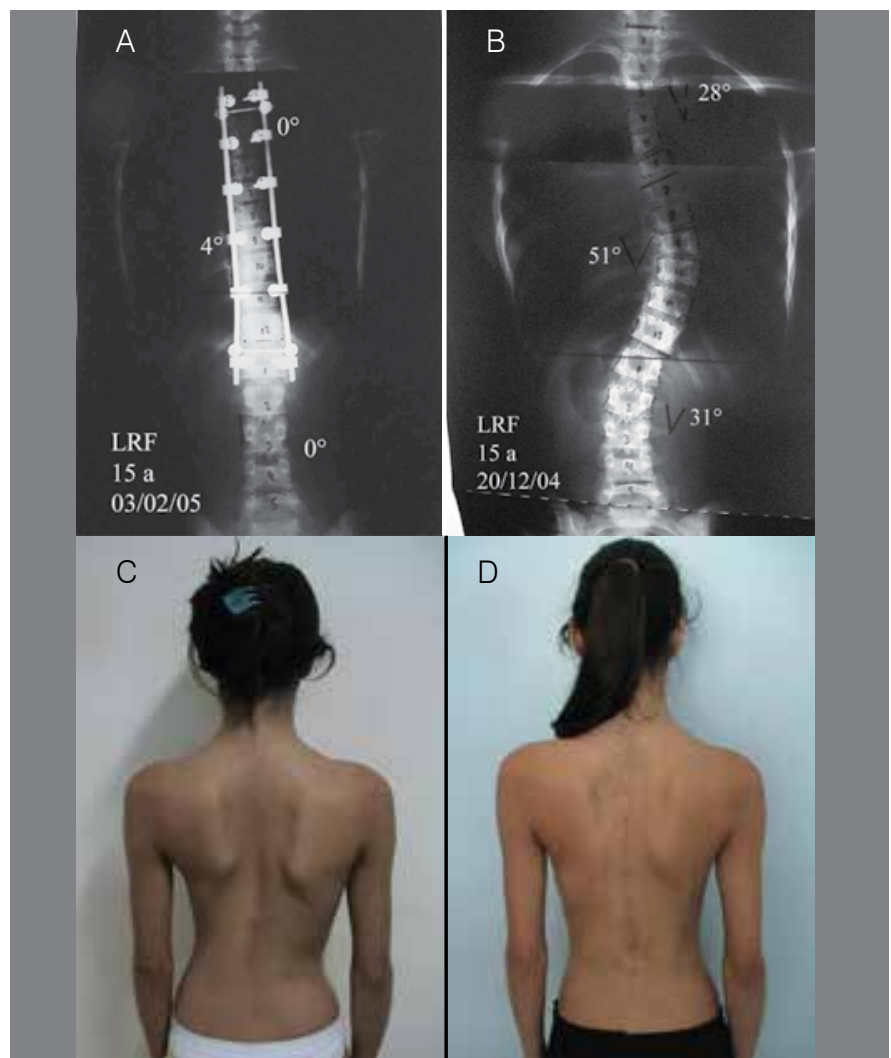

Figure 6. $15 \mathrm{a}$, Instrumentation of $50 \%$ of the pedicles. Radigraphs and photos pre $(A$ and $C)$ and postoperative $(B$ and $D)$.

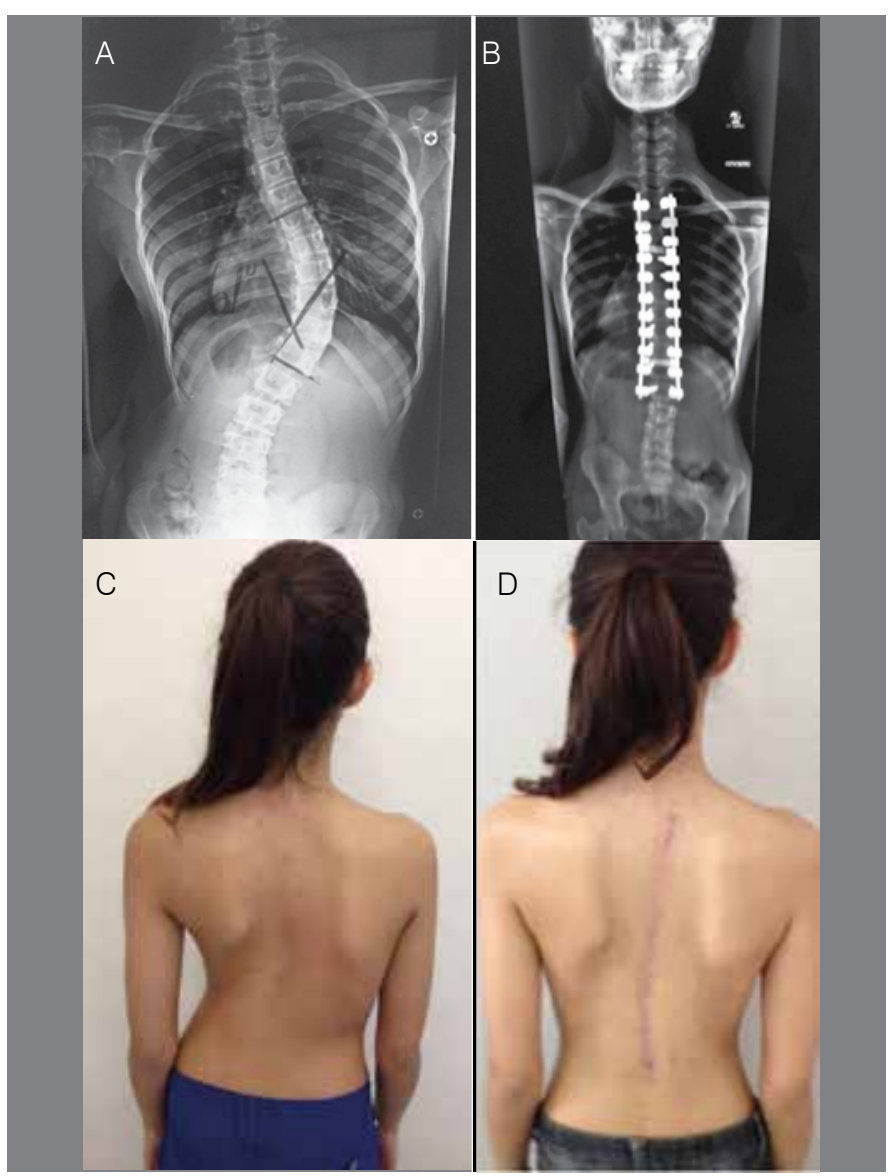

Figure 7. 13 a, Instrumentation of $100 \%$ of the pedicles.Radigraphs and photos pre $(A$ and $C)$ and postoperative $(B$ and $D)$.

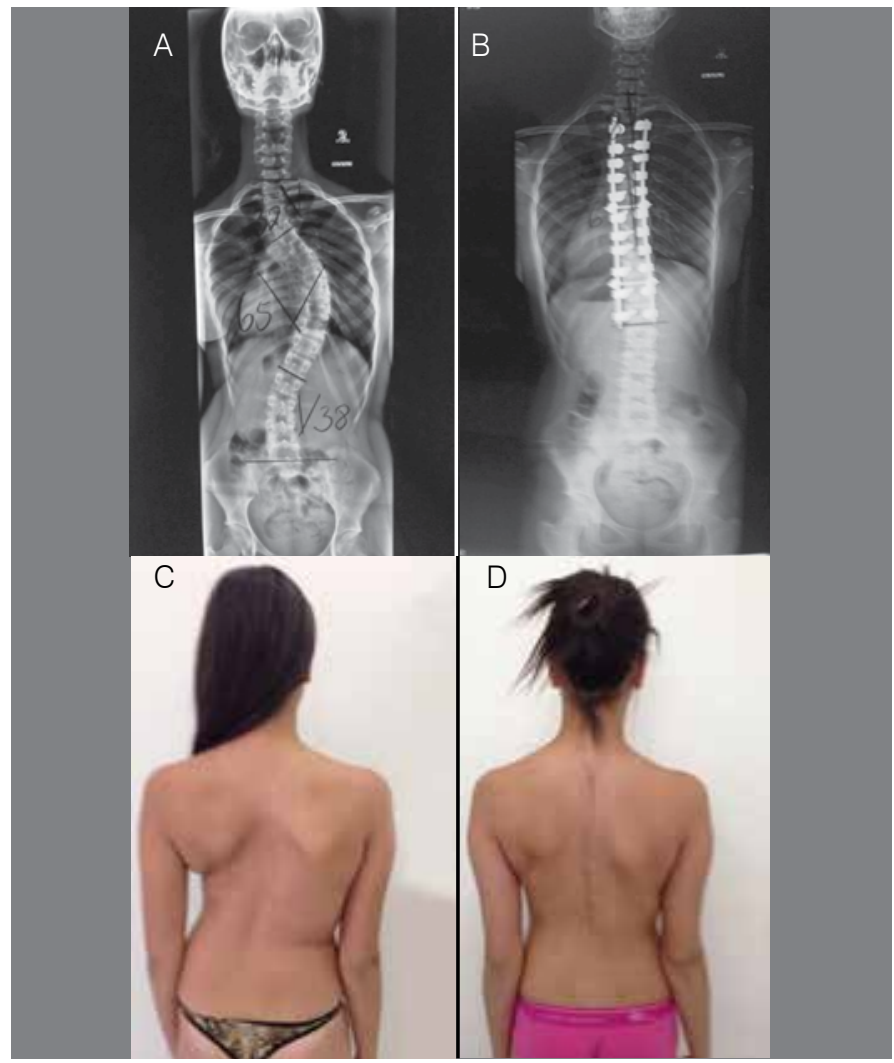

Figure 8. $15 \mathrm{a}$, Instrumentation of $100 \%$ of the pedicles. Radigraphs and photos pre $(A$ and $C)$ and postoperative $(B$ and $D)$.

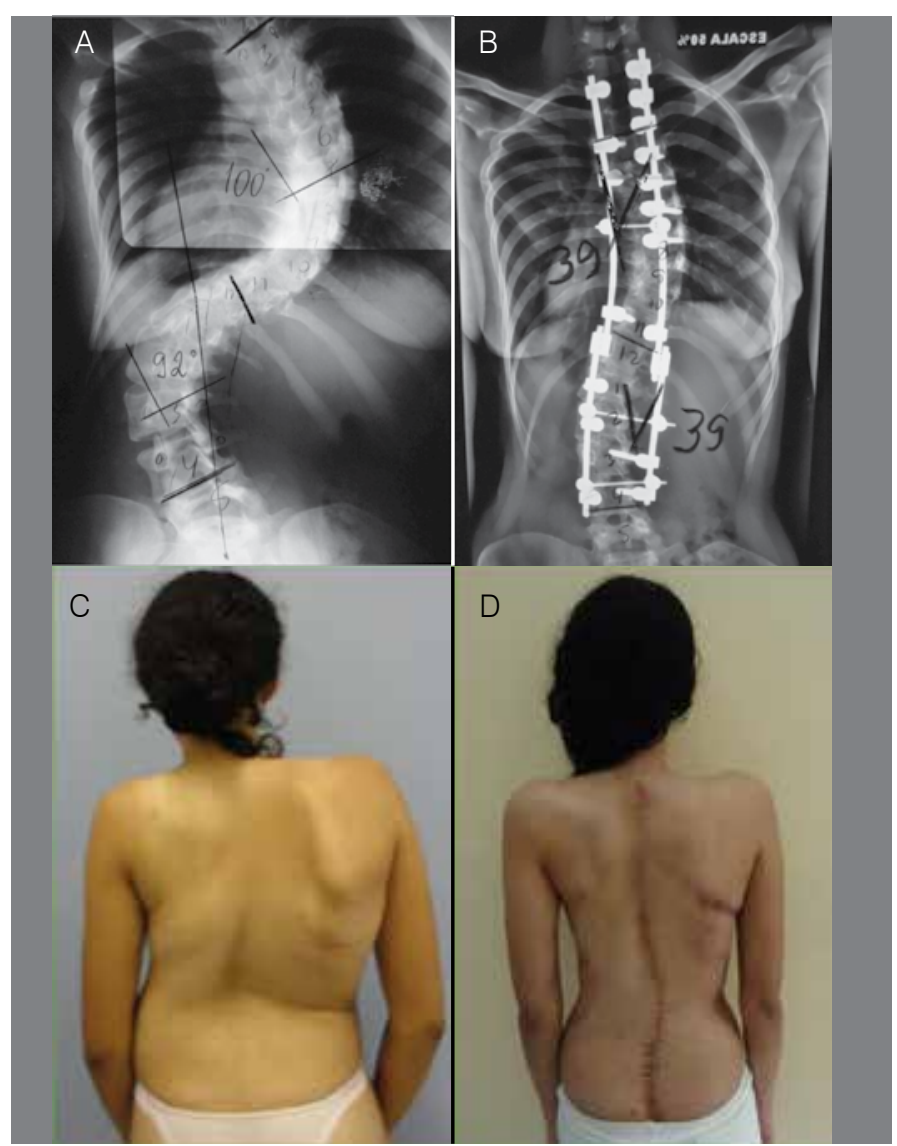

Figure 9. 16 a, Correction of very severe deformity, anterior and posterior approach.Instrumentation of $50 \%$ of the pedicles. Radigraphs and photos pre ( $A$ and $C$ ) and postoperative (B and $D)$. 


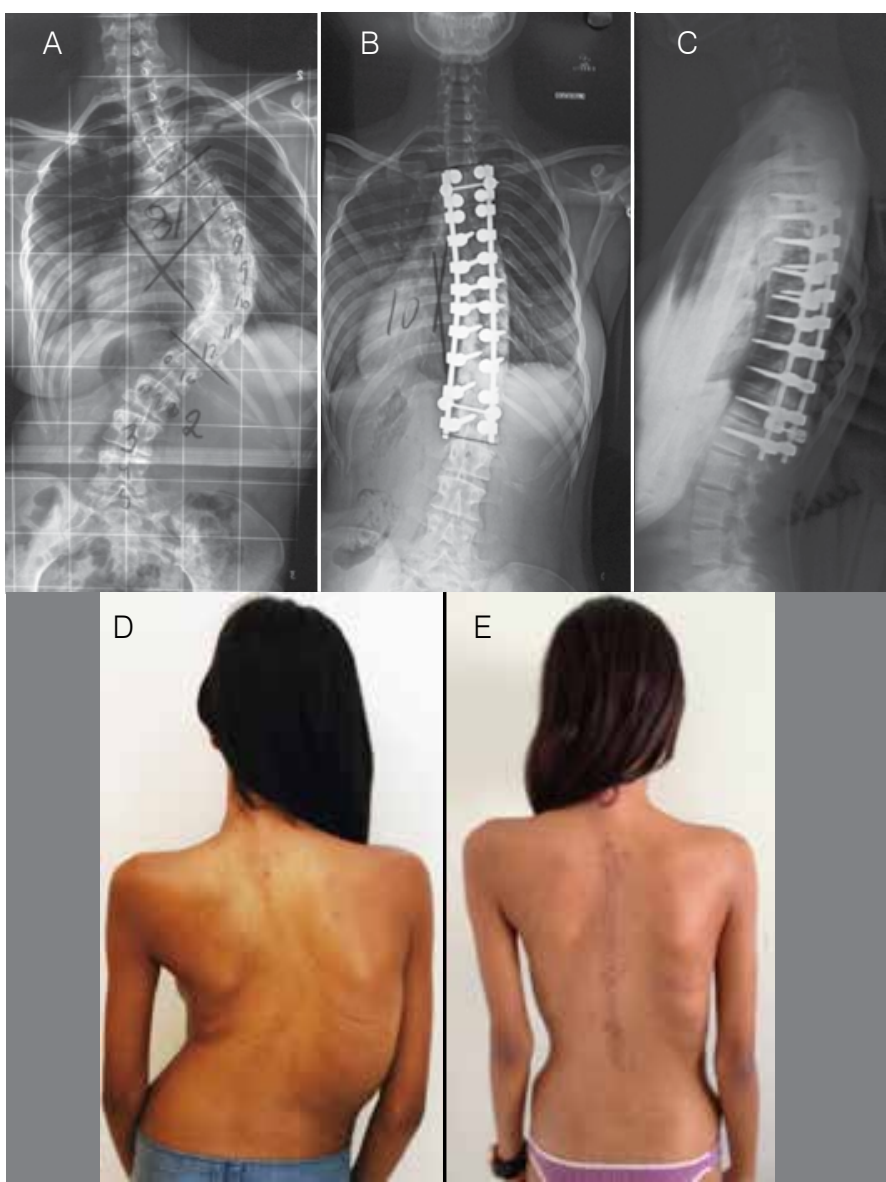

Figure 10. $17 \mathrm{a}$, Instrumentation of $100 \%$ of the pedicles. Radigraphs and photos pre $(A$ and $D)$ and postoperative $(B, C$ e E).

Daher et $\mathrm{al},{ }^{7}$ concluded that in the surgical treatment of neuromuscular scoliosis the correction of the curve increases as the implant density increases.

Gotfryd ${ }^{8}$ studied and compared two groups of 23 patients with AIS who underwent surgeries with higher and lower implant density.
No statistically significant difference was observed in the radiological results, but greater correction of the ribcage was shown.

Like the authors above, we found that the two groups (100\% fixation screw density and up to $50 \%$ fixation screw density) presented a statistically significant difference in favor of $100 \%$ fixation. (Figure 3 )

Bharucha et al. ${ }^{9}$ conducted a retrospective study of 91 patients with Lenke 1 curves. There was no evidence of an advantage to using high-density implants in more flexible curves in patients with AIS. We emphasize that this author only evaluated flexible curves so a comparison of results between groups with more severe curves and with patterns more complex than Lenke 1 could show differences in effectiveness between using low- and high-density implants.

Quan and Gibson ${ }^{10}$ conducted a retrospective study of 49 patients with Lenke 1 curves. There was no confirmed relationship between implant density and the degree of postsurgical correction.

Gebhart et al. ${ }^{11}$ conducted a retrospective study of 119 patients with AIS (Lenke 1, 2, 3, 4, and 6). The correction of the principal thoracic curve was closely correlated with the flexibility of the curve and not with the density of the screws.

In spite of the fact that certain authors did not confirm greater correction in relation to implant density, it is expected that a greater number of points of support promote better correction, greater stability, and greater vertebral rotation, although the correction of vertebral rotation is not evaluated in most of the studies conducted. An improvement in this correction was observed in the paper by Gotfryd in 2012 and also in our study. It is also wise to remember that greater screw density increases both morbidity and cost.

We suggest, therefore, that common sense be used in each situation, considering factors like the severity of the curve, rotation, age, and the degree of flexibility of the deformity.

\section{CONCLUSION}

This biostatistical study showed that the group with up to $50 \%$ screw density had a rate of correction of $82.1 \%$ and the group with $100 \%$ density was corrected to around $86.8 \%$. We conclude, therefore, that the difference is statistically significant and in favor of fixation with a density of $100 \%$ ( $p$-value $=0.010)$.

All authors declare no potential conflict of interest concerning this article.

CONTRIBUTIONS OF THE AUTHORS: Each author made a significant individual contribution to the development of the manuscript. EBE was the main author, pioneer of the work, and supervisor. LFG, EBGJ and RGG carried out the evaluation of patients' records and the data collection. STG, FHRO, VAB and WPC conducted the literature review.

\section{REFERENCES}

1. Josette Bettany-Saltikov, Hans-Rudolf Weiss, Nachiappan Chockalingam Surgical versus non-surgical interventions in patients with adolescent idiopathic scoliosis. Editorial Group: Cochrane Back Group. Published Online: 31 JUL 2013

2. Clements DH, Betz RR, Newton PO, Rohmiller M, Marks MC, Bastrom T. Correlation of scoliosis curve correction with the number and type of fixation anchors. Spine (Phila Pa 1976). 2009:34(20):2147-50

3. Yilmaz G, Borkhuu B, Dhawale AA, Oto M, Littleton AG, Mason DE, et al. Comparative analysis of hook, hybrid, and pedicle screw instrumentation in the posterior treatment of adolescent idiopathic scoliosis. J Pediatr Orthop. 2012;32(5):490-9.

4. Garcia EB, Gonçalves RG, Ribeiro GO, Garcia JF, Garcia LF Instrumentação de terceira geração na escoliose idiopática do adolescente - Coluna/Columna. 2006;5(1):13-8.

5. Chen J Yang C. Ran B, Wang Y Wang C, Zhu X, et al. Correction of Lenke 5 adolescent idiopathic scoliosis using pedicle screw instrumentation: does implant density influence the correction? Spine (Phila Pa 1976). 2013;38(15):E946-51.

6. Larson AN, Polly DW Jr, Diamond B, Ledonio C, Richards BS 3rd, Emans JB, et al. Does higher anchor density result in increased curve correction and improved clinical outcomes in adolescent idiopathic scoliosis? Spine (Phila Pa 1976). 2014;39(7):571-8.
7. Daher MT, Cavali PTM, Santo MAM, Rossato AJ, Lehoczki MA, Landim E. Correlação entre o número de parafusos e o percentual de correção no tratamento cirúrgico da escoliose neuromuscular. Coluna/Columna. 2009:8(2):105-9.

8. Gotfryd AO. Tratamento cirúrgico da escoliose idiopática do adolescente com parafusos pediculares: a densidade de implante influencia nos resultados clínicos e radiográficos? Ensaio clínico randomizado [tese]. São Paulo: Faculdade de Ciências Médicas da Santa Casa de São Paulo; 2012.

9. Bharucha NJ, Lonner BS, Auerbach JD, Kean KE, Trobisch PD. Low-density versus high-density thoracic pedicle screw constructs in adolescent idiopathic scoliosis: do more screws lead to a better outcome? Spine J. 2013;13(4):375-81

10. Quan GM, Gibson MJ. Correction of main thoracic adolescent idiopathic scoliosis using pedicle screw instrumentation: does higher implant density improve correction? Spine (Phila Pa 1976). 2010:35(5):562-7.

11. Gebhart S, AltonTB, Bompadre V, KrengelWF. Do anchor density or pedicle screw density correlate with short-term outcome measures in adolescent idiopathic scoliosis surgery? Spine (Phila Pa 1976). 2014;39(2):E104-10 